\title{
Architectures de pierre dans le Dekkan et le malwa avant l'époque Moghole
}

Klaus Rötzer

\section{(2) OpenEdition}

1 Journals

Édition électronique

URL : https://journals.openedition.org/tc/763

DOI : $10.4000 /$ tc. 763

ISSN : 1952-420X

Éditeur

Éditions de l'EHESS

Édition imprimée

Date de publication : 1 octobre 1990

ISSN : 0248-6016

\section{Référence électronique}

Klaus Rötzer, «Architectures de pierre dans le Dekkan et le malwa avant l'époque Moghole »,

Techniques \& Culture [En ligne], 14 | 1990, mis en ligne le 16 janvier 2006, consulté le 29 septembre

2022. URL : http://journals.openedition.org/tc/763 ; DOI : https://doi.org/10.4000/tc.763

Ce document a été généré automatiquement le 29 septembre 2022.

Tous droits réservés 


\section{Architectures de pierre dans le Dekkan et le malwa avant l'époque Moghole}

Klaus Rötzer 